\title{
Thermus silvanus sp. nov. and Thermus chliarophilus sp. nov., Two New Species Related to Thermus ruber but with Lower Growth Temperatures
}

\author{
SANDRA TENREIRO, ${ }^{1}$ M. FERNANDA NOBRE, ${ }^{2}$ AND MILTON S. DA COSTA ${ }^{1 *}$ \\ Departamento de Bioquímica, Universidade de Coimbra, 3000 Coimbra, ${ }^{1}$ and Departamento de Zoologia, \\ Universidade de Coimbra, 3049 Coimbra Codex, ${ }^{2}$ Portugal
}

\begin{abstract}
Strains of Thermus silvanus sp. nov. and strains of Thermus chliarophilus sp. nov. were isolated from the hot spring at Vizela in northern Portugal and the hot spring at Alcafache in central Portugal, respectively. The strains of $T$. silvanus produce orange-red-pigmented colonies and have an optimum growth temperature of about $55^{\circ} \mathrm{C}$, while the strains of $T$. chliarophilus produce yellow-pigmented colonies and have an optimum growth temperature of about $50^{\circ} \mathrm{C}$. The strains of both species are catalase negative. These species can be distinguished from each other and from Thermus ruber by biochemical characteristics, fatty acid composition data, and 16S rRNA gene sequence data. Our phylogenetic analysis showed that strains VI-R2 ${ }^{\mathrm{T}}(\mathrm{T}=$ type strain) and ALT $-8^{\mathrm{T}}$ belong to the $T$. ruber line of descent. The type strain of $T$. silvanus is strain VI-R2 (= DSM 9946), and the type strain of $T$. chliarophilus is strain ALT-8 (= DSM 9957).
\end{abstract}

Five species of bacteria belonging to the genus Thermus have been validly described previously. Thermus aquaticus (1) was described on the basis of strains isolated at Yellowstone National Park; the description of Thermus filiformis (7) was based on one filamentous strain from New Zealand; Thermus scotoductus (9) was described on the basis of nonpigmented strains from Iceland and the United States; and Thermus thermophilus was validly described (16) but was not included on the Approved Lists of Bacterial Names (26) or on subsequent validation lists because it could not be distinguished from T. aquaticus. However, it is now possible to distinguish T. thermophilus from the other Thermus species by using DNA homology data and phenotypic characteristics $(13,14,31)$. The species mentioned above produce yellow-pigmented or nonpigmented colonies, have optimum growth temperatures between 70 and $75^{\circ} \mathrm{C}$, and are commonly designated the high-temperature species of the genus Thermus.

Thermus ruber strains (11) have optimum growth temperatures of 60 to $65^{\circ} \mathrm{C}$ and maximum growth temperatures of just less than $70^{\circ} \mathrm{C}$ and form red-pigmented colonies. Despite the extensive geographical distribution of this species and its phenotypic diversity, all of the strains that have been examined exhibit high levels of DNA homology $(6,20,23)$.

Recently, we isolated several orange-red-pigmented Thermus strains from the hot spring at Vizela in northern Portugal and yellow-pigmented Thermus strains from the hot spring at Alcafache in central Portugal and found that these organisms had low optimum growth temperatures. In this paper we describe two new Thermus species that are related to T. ruber on the basis of biochemical and tolerance characteristics, chemotaxonomic parameters, and 16S rRNA gene sequences. We propose the names Thermus silvanus and Thermus chliarophilus for these new species.

\section{MATERIALS AND METHODS}

Isolation and bacterial strains. Strains VI-R1, VI-R2 ${ }^{\mathrm{T}}(\mathrm{T}=$ type strain), VI-R7, VI-R11, and VI-R12 (the VI-R strains) were isolated from the hot spring

* Corresponding author. Mailing address: Departamento de Bioquimica, Apartado 3126, Universidade de Coimbra, 3000 Coimbra, Portugal. Phone: 351-39-29802. Fax: 351-39-26798. (vent temperature, $56^{\circ} \mathrm{C}$; $\mathrm{pH} 8.9$ ) located at the end of a $450-\mathrm{m}$ tunnel and from thermal water (temperature, $33^{\circ} \mathrm{C} ; \mathrm{pH} 8.8$ ) piped to a spa at Vizela in northern Portugal. Strains ALT $-8^{\mathrm{T}}$, ALT-9, and ALT-10 (the ALT strains) were isolated from the hot spring at Alcafache (vent temperature, $50^{\circ} \mathrm{C} ; \mathrm{pH} 8.0$ ) in central Portugal. Water samples were filtered through membrane filters (Gelman type GN-6; pore size, $0.45 \mu \mathrm{m}$; diameter, $47 \mathrm{~mm}$ ); the filters were placed on the surfaces of Thermus agar plates (32), and these preparations were wrapped in plastic bags and incubated at $50^{\circ} \mathrm{C}$ for up to 7 days. Strain VI-R1 was recovered 3 years before the other strains from plates incubated at $60^{\circ} \mathrm{C}$ by using the methods described above. Cultures were purified by subculturing and were kept at $-80^{\circ} \mathrm{C}$ in Thermus medium containing $15 \%$ glycerol.

Several $T$. nuber strains were used for comparative purposes. T. ruber DSM $1279^{1}$ and "Thermus rubens" ATCC 31556 were obtained from the Deutsche Sammlung von Mikroorganismen und Zellkulturen, Braunschweig, Germany, and the American Type Culture Collection, Rockville, Md., respectively. Strains MTL-16501 and MTL-16503 from the Azores, strains MTL-16105 and MTL16106 from Iceland, strains MTL-16234 and MTL-16294 from New Zealand, and strains MTL-15056 and MTL-15057 from the United States were kindly donated by R. Sharp, Microbial Technology Laboratory, Centre for Applied Microbiology \& Research, Salisbury, United Kingdom. Strains SPS-R1, SPS-R4, and SPS-R7 were isolated from the hot spring at São Pedro do Sul, Portugal, and have been described previously (4).

Biochemical and tolerance characteristics. Unless otherwise stated, all biochemical and tolerance tests were performed as described previously $(13,21)$ in Thermus medium or on Thermus agar incubated at $50^{\circ} \mathrm{C}$ for up to 5 days. Catalase activity was examined by using the methods described by Vesey et al. (29) and Smibert and Krieg (27). The growth temperature ranges of $T$. ruber DSM $1279^{\mathrm{T}}, \mathrm{VI}-\mathrm{R} 2^{\mathrm{T}}$, and ALT $-8^{\mathrm{T}}$ were determined by incubating $300-\mathrm{ml}$ metalcapped Erlenmeyer flasks containing $100 \mathrm{ml}$ of Thermus medium in a reciprocal water bath shaker. The $\mathrm{pH}$ ranges for growth were determined in Thermus medium as described above by using $20 \mathrm{mM}$ MES [2-( $N$-morpholino)ethanesulfonic acid] for $\mathrm{pH}$ values between 5.0 and 6.5 , Tris for $\mathrm{pH}$ values between 7.0 and 8.5, and CAPSO [3-(cyclohexylamino)-2-hydroxy-1-propanesulfonic acid] for $\mathrm{pH}$ values between 9.0 and 10.5 ; the $\mathrm{pH}$ of each buffer was adjusted with $\mathrm{HCl}$ or $\mathrm{NaOH}$. The $\mathrm{pH}$ values were always determined at room temperature.

Single-carbon-source assimilation tests were performed in a minimal medium composed of Thermus basal salts medium without nitrate to which filter-sterilized carbon sources $\left(2.0 \mathrm{~g}\right.$ liter $\left.{ }^{-1}\right)$, ammonium sulfate $\left(0.5 \mathrm{~g} \mathrm{liter}^{-1}\right)$, and yeast extract $\left(0.2 \mathrm{~g} \mathrm{liter}^{-1}\right)$ were added. Growth was examined by measuring the turbidity of cultures incubated at $50^{\circ} \mathrm{C}$ with shaking in $300 \mathrm{ml}$ metal-capped Erlenmeyer flasks containing $100 \mathrm{ml}$ of medium every $12 \mathrm{~h}$ for 3 days. Positive and negative control cultures were grown in Thermus medium and in minimal medium without a carbon source, respectively.

Electron microscopy. Cultures were grown for $24 \mathrm{~h}$ in Thermus medium at $50^{\circ} \mathrm{C}$, washed by centrifugation, prefixed for $16 \mathrm{~h}$ at room temperature in $2.5 \%$ gluteraldehyde in $0.1 \mathrm{M}$ cacodylate buffer at $\mathrm{pH} 7.2$, washed in the same buffer, and fixed in $1 \% \mathrm{OsO}_{4}$ in Veronal-acetate buffer $(\mathrm{pH} 6.2$ ) containing $10.0 \mathrm{mM}$ $\mathrm{NaCl}$ and $10.0 \mathrm{mM} \mathrm{CaCl}$ for $16 \mathrm{~h}$ at room temperature (25). The cells were washed in water and postfixed for $30 \mathrm{~min}$ at room temperature in $1.0 \%$ uranyl acetate. The pellets were dehydrated with ethanol and embedded in Epon. Ultrathin sections were double contrasted by using uranyl lead (25) or a modification of the Thiéry method (24). 
Polar lipid, lipoquinone, and fatty acid compositions. The cultures used for polar lipid analysis were grown in 1-liter Erlenmeyer flasks containing $200 \mathrm{ml}$ of Thermus medium at $50^{\circ} \mathrm{C}$ in a reciprocal water bath shaker until the late exponential phase of growth. Harvesting of the cultures, extraction of the lipids, and two-dimensional thin-layer chromatography were performed as described previously (18).

Lipoquinones were extracted from freeze-dried cells and were purified by thin-layer chromatography as described by Tindall (28). The lipoquinones were separated with a Gilson high-performance liquid chromatography apparatus by using a reverse-phase (RP18) Spherisorb S5 ODS2 column and methanol-heptane $(10: 2, \mathrm{vol} / \mathrm{vol})$ as the mobile phase and were detected at $269 \mathrm{~nm}$.

The cultures used for fatty acid analysis were grown on Thermus agar plates in sealed plastic bags submerged in a water bath at $50^{\circ} \mathrm{C}$ for $24 \mathrm{~h}$. Fatty acid methyl esters were obtained from fresh wet biomass by saponification, methylation, and extraction as described previously (10). The fatty acid methyl esters were separated by using a Hewlett-Packard model 5890 gas chromatograph equipped with a flame ionization detector and a $5 \%$ phenylmethyl silicone capillary column $(0.2 \mathrm{~mm}$ by $25 \mathrm{~m}$; Hewlett-Packard $)$. The carrier gas was high-purity $\mathrm{H}_{2}$; the column head pressure was $60 \mathrm{kPa}$; the septum purge rate was $5 \mathrm{ml} / \mathrm{min}$; the column split ratio was $55: 1$; and the injection port temperature was $300^{\circ} \mathrm{C}$. The temperature of the oven was programmed to increase from 170 to $270^{\circ} \mathrm{C}$ at a rate of $5^{\circ} \mathrm{C} / \mathrm{min}$. Identification and quantification of the fatty acid methyl esters, as well as a numerical analysis of the fatty acid profiles, were performed by using the standard MIS library generation software (Microbial ID, Inc., Newark, Del.)

DNA base composition and $16 \mathrm{~S}$ rDNA sequence analysis. The DNAs used to determine DNA base compositions were isolated as described by Cashion et al (2). The $\mathrm{G}+\mathrm{C}$ content of the DNA was determined by high-performance liquid chromatography as described by Mesbah et al. (15). A 16S ribosomal DNA (rDNA) sequence analysis was performed by using the methods for genomic DNA extraction, PCR-mediated amplification of the $16 \mathrm{~S}$ rDNA, and purification of the PCR products described previously $(18,19)$. Purified PCR products were sequenced by using a Taq Dye-Deoxy Terminator Cycle Sequencing Kit (Applied Biosystems, Foster City, Calif.) as recommended by the manufacturer. Sequence reaction mixtures were electrophoresed by using an Applied Biosystems mode 373A DNA sequencer. The $16 \mathrm{~S}$ rDNA sequences were manually aligned with representative sequences from members of the Thermus line of descent (22) Pairwise evolutionary distances were compared by using the correction of Jukes and Cantor (8). The least-squares distance method of DeSoete (3) was used to construct a phylogenetic dendrogram from the distance matrices.

Nucleic acid sequence accession numbers. Our $16 \mathrm{~S}$ rDNA sequence data are available from the EMBL data library under accession number X84211 for strain VI-R2 ${ }^{\mathrm{T}}$ and accession number X84212 for strain ALT- $8^{\mathrm{T}}$.

\section{RESULTS}

Isolation of strains. Strain VI-R1 was isolated at $60^{\circ} \mathrm{C}$, but later it was found that this strain grows slowly at this temperature in a liquid medium and that its fatty acid composition is different from the fatty acid compositions of other $T$. ruber strains (4). These observations led to subsequent isolation attempts in which samples obtained from Vizela in northern Portugal and Alcafache and São Gemil in central Portugal were incubated at $50^{\circ} \mathrm{C}$. Thermus strains were isolated from the water samples obtained from Vizela and Alcafache after membrane filters were incubated at $50^{\circ} \mathrm{C}$ for 3 days. Orange-redpigmented colonies were isolated from Vizela, and yellowpigmented colonies were isolated from Alcafache. On the basis of polar lipid and fatty acid analysis data none of the other organisms isolated, except the nonpigmented high-temperature strains obtained from the Vizela samples, was considered a member of the genus Thermus.

Morphological, biochemical, and tolerance characteristics. All of the strains formed rod-shaped cells of various lengths and short filaments in liquid media and on solid media. Transmission electron microscopy showed that the cells of strains VI-R2 ${ }^{\mathrm{T}}$ and ALT $-8^{\mathrm{T}}$ had an envelope consisting of a threelayer, symmetric cytoplasmic membrane and a cell wall with an inner, electron-dense thin layer, which presumably represented the peptidoglycan. An outer corrugated layer was connected to the peptidoglycan by irregularly spaced invaginations (Fig. 1a). Strain VI-R2 ${ }^{\mathrm{T}}$ was shown by Thiéry staining to have polysaccharide inclusions (Fig. 1b).

The optimum growth temperatures were about $55^{\circ} \mathrm{C}$ for strain VI-R2 $2^{\mathrm{T}}$ and about $50^{\circ} \mathrm{C}$ for strain ALT $-8^{\mathrm{T}}$. No growth occurred at or below $35^{\circ} \mathrm{C}$; strain ALT $-8^{\mathrm{T}}$ did not grow at temperatures above $60^{\circ} \mathrm{C}$, while strain VI-R2 ${ }^{\mathrm{T}}$ did not grow at temperatures above $65^{\circ} \mathrm{C}$. On the other hand, T. ruber DSM $1279^{\mathrm{T}}$ had an optimum growth temperature of about $65^{\circ} \mathrm{C}$ but did not grow at $70^{\circ} \mathrm{C}$ (Fig. 2a). Growth of strains VI-R2 $2^{\mathrm{T}}$ and ALT $-8^{\mathrm{T}}$ was not observed at $\mathrm{pH}$ values below 5.5 or above 10.0 (Fig. 2b). Growth of these organisms did not occur in Thermus basal salts medium containing glucose and $\left(\mathrm{NH}_{4}\right)_{2} \mathrm{SO}_{4}$; yeast extract was necessary for the growth of all of the VI-R and ALT strains. None of the strains grew under anaerobic conditions in the absence of nitrate; deep stab cultures in soft Thermus agar resulted in profuse growth only at the surface.

All of the strains were oxidase positive; the VI-R and the ALT strains were catalase negative as determined by the two methods used to assess the presence of this enzyme, while all of the strains assigned to $T$. ruber were catalase positive as determined by both methods. The VI-R and the ALT strains reduced nitrate to nitrite, while T. ruber DSM $1279^{\mathrm{T}}$ did not. Assimilation of single carbon sources could not be assessed in static tubes or on petri plates containing minimal medium because of erratic growth. However, it was possible to measure growth in shake cultures. Other biochemical and tolerance characteristics that distinguish the strains are shown in Table 1. The only differences in the assimilation of the single carbon sources tested were the utilization of xylose and ribitol by VI-R1 and VI-R2 ${ }^{\mathrm{T}}$ and the utilization of sucrose and trehalose by ALT $-8^{\mathrm{T}}$ and ALT-10.

Polar lipids, respiratory quinones, and fatty acids. The polar lipids of the VI-R strains, the ALT strains, and the T. ruber strains consisted of one major phospholipid and two prominent glycolipids that migrated close to the origin. Two additional minor glycolipids and one minor phospholipid were also present in all of the strains (data not shown). Menaquinone 8 was the only respiratory lipoquinone detected in all strains.

The major fatty acids of all of the organisms which we examined were iso- and anteiso-branched acids (Table 2). All of the strains examined contained a distinctive $17: 02 \mathrm{OH}$ iso fatty acid in moderate amounts. However, major differences in the fatty acid compositions of the strains of the three species were observed after growth at $50^{\circ} \mathrm{C}$; in the T. ruber and ALT strains 15:0 iso and 17:0 iso acids were present in higher proportions than the corresponding anteiso fatty acids, while in the VI-R strains 15:0 iso and 15:0 anteiso acids were the major fatty acids and 17:0 iso and 17:0 anteiso acids were minor components. At this growth temperature, branched-chain monounsaturated fatty acids, which were present in moderate amounts in the $T$. ruber strains, were virtually absent in the ALT and the VI-R strains. At the optimum growth temperatures, the $T$. ruber strains could not be distinguished from the ALT strains because of the absence of $17: 1 \omega 9 \mathrm{c}$ iso acid in $T$. ruber.

16S rRNA gene sequence analysis. The $16 \mathrm{~S}$ rDNA similarity matrix in Table 3 shows that strains ALT $-8^{\mathrm{T}}$ and VI-R2 ${ }^{\mathrm{T}}$ are more closely related to $T$. ruber DSM $1279^{\mathrm{T}}$ than to the hightemperature Thermus species. The level of 16S rRNA gene sequence similarity for strains ALT $-8^{\mathrm{T}}$ and VI-R $2^{\mathrm{T}}$ was $88.5 \%$. Moreover, strains VI-R2 ${ }^{\mathrm{T}}$ and ALT $-8^{\mathrm{T}}$ exhibited levels of sequence similarity of 90.0 and $91.2 \%$ with $T$. ruber, respectively. Lower levels of sequence relatedness were observed with the high-temperature Thermus species (approximately 85 to 86\%). Our phylogenetic tree showed that strains ALT- $8^{\mathrm{T}}$ and VI-R2 ${ }^{\mathrm{T}}$ 

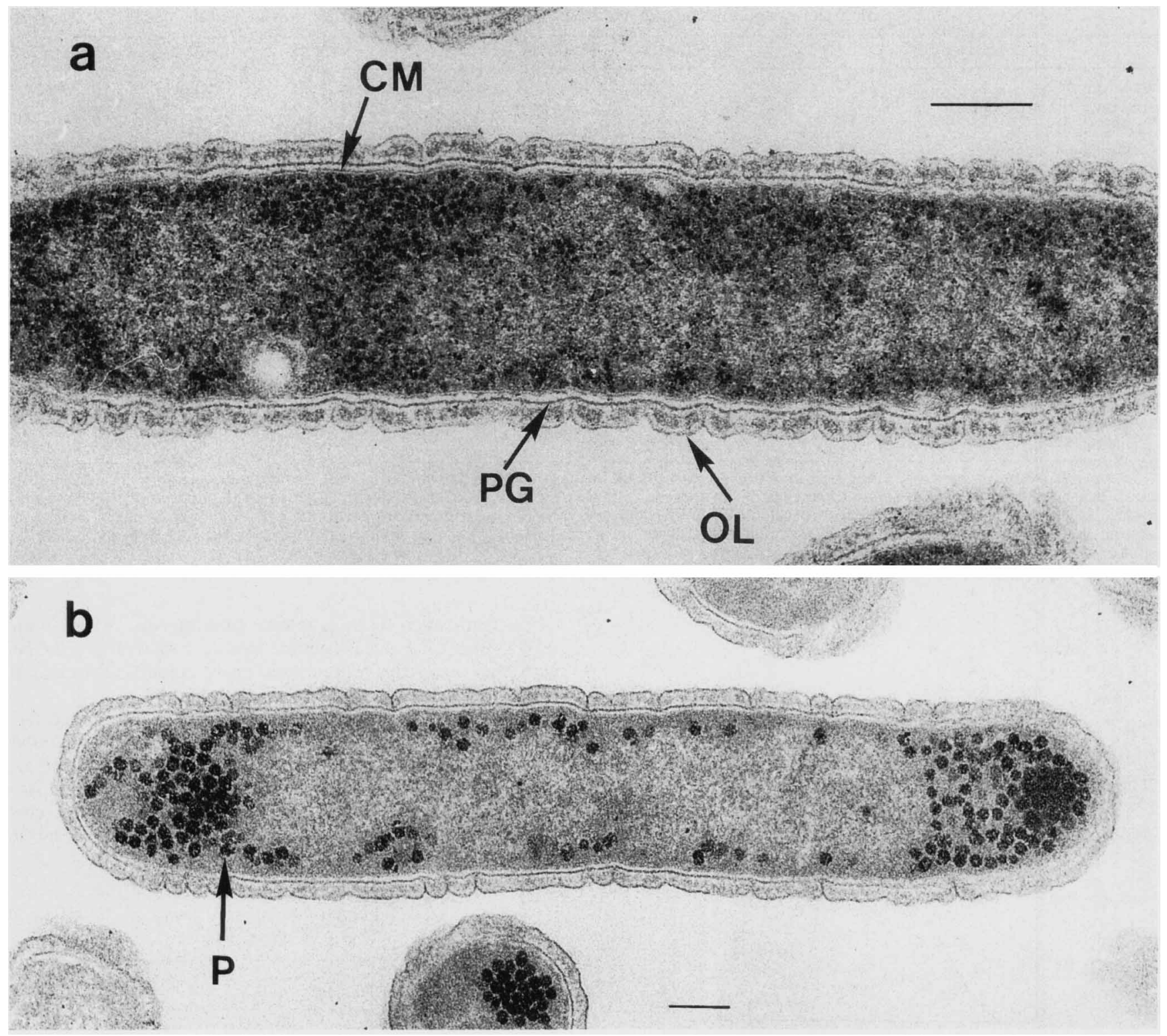

FIG. 1. Ultrastructure of strain VI-R2 ${ }^{\mathrm{T}}$. (a) Thin section contrasted with uranyl lead showing the outer layer (OL), peptidoglycan (PG), and cytoplasmic membrane (CM). Bar $=0.2 \mu \mathrm{m}$. (b) Thin section stained by the Thiéry method showing polysaccharide inclusions $(\mathrm{P})$. Bar $=0.2 \mu \mathrm{m}$.

diverged from the T. ruber line of descent and that yellowpigmented strain ALT $-8^{\mathrm{T}}$ was more closely related to $T$. ruber DSM $1279^{\mathrm{T}}$ than VI-R2 ${ }^{\mathrm{T}}$ was (Fig. 3).

\section{DISCUSSION}

The 16S rRNA gene sequences of red-pigmented strain VI$\mathrm{R} 2^{\mathrm{T}}$ and yellow-pigmented strain ALT- $8^{\mathrm{T}}$ show that these organisms represent two new species that are related to but distinct from $T$. ruber. The evolutionary distances that separate the three species in the T. ruber line of descent are, in fact, greater than the evolutionary distances that separate the Thermus species with optimum growth temperatures of 70 to $75^{\circ} \mathrm{C}$ (22). The Thermus and Deinococcus species form one deeply branching phylum in the evolution of the bacteria (30). Within the genus Thermus, one line of descent appears to have given rise to species with high optimum growth temperatures, and the other appears to have given rise to species with low optimum growth temperatures. Our results also show that the diversity of the "low-temperature" Thermus species may be as great as the diversity of the high-temperature species of this genus.

The major physiological and biochemical characteristics that distinguish the ALT and VI-R strains from T. ruber are the lower growth temperature range, the reduction of nitrate to nitrite, and the absence of catalase activity in the ALT and VI-R strains. Strain VI-R2 ${ }^{\mathrm{T}}$ and VI-R1 can be distinguished from strains ALT $-8^{\mathrm{T}}$ and ALT -10 on the basis of pigmentation, the presence of $\alpha$-galactosidase in strains ALT $-8^{\mathrm{T}}$ and ALT-10, the assimilation of xylose and ribitol by strains VI-R2 ${ }^{\mathrm{T}}$ and VI-R1, and the assimilation of sucrose and trehalose by strains ALT $-8^{\mathrm{T}}$ and ALT -10 . 
TABLE 1. Biochemical and tolerance characteristics that distinguish strains after growth at $50^{\circ} \mathrm{C}$

\begin{tabular}{|c|c|c|c|c|c|}
\hline Characteristic & T. ruber DSM $1279^{\mathrm{T}}$ & Strain VI-R1 & Strain VI-R2 ${ }^{\mathrm{T}}$ & Strain ALT $-8^{\mathrm{T}}$ & Strain ALT-10 \\
\hline Pigmentation & Red & Orange-red & Orange-red & Yellow & Yellow \\
\hline \multicolumn{6}{|l|}{ Growth in the presence of: } \\
\hline $1.0 \% \mathrm{NaCl}$ & $+^{a}$ & - & - & + & + \\
\hline $2.0 \% \mathrm{NaCl}$ & + & - & - & - & - \\
\hline Hydrolysis of starch ( 5 days) & - & + & + & + & + \\
\hline \multicolumn{6}{|l|}{ Presence of: } \\
\hline$\alpha$-Galactosidase & + & - & - & + & + \\
\hline Catalase & + & - & - & - & - \\
\hline Degradation of $p$-nitrophenyl- $\beta$-glucopyranoside & + & - & - & + & + \\
\hline \multicolumn{6}{|l|}{ Utilization of: } \\
\hline D-Xylose & + & + & + & - & - \\
\hline Sucrose & + & - & - & + & + \\
\hline D-Cellobiose & + & + & - & + & + \\
\hline D-Trehalose & + & - & - & + & + \\
\hline Glycerol & + & - & + & - & - \\
\hline Ribitol & - & + & + & - & - \\
\hline myo-Inositol & + & - & - & - & - \\
\hline Salicin & + & - & - & - & - \\
\hline
\end{tabular}

$"+$, positive result or growth; -, negative result or no growth. All of the organisms hydrolyzed elastin, fibrin, casein, gelatin, and hide powder azure, degraded arbutin, esculin, hippurate, and $p$-nitrophenyl- $\alpha$-glucopyranoside, reduced tellurite $(0.1 \%$, wt/vol), and were $\beta$-galactosidase positive. D-Glucose, D-fructose, D-mannose, D-galactose, maltose, lactose, D-melibiose, D-mannitol, D-sorbitol, pyruvate, L-glutamate, L-asparagine, L-serine, L-glutamine, and L-proline were assimilated by all of the strains. None of the strains utilized L-arabinose, L-rhamnose, D-raffinose, meso-erythritol, acetate, succinate, citrate, or acetamide.
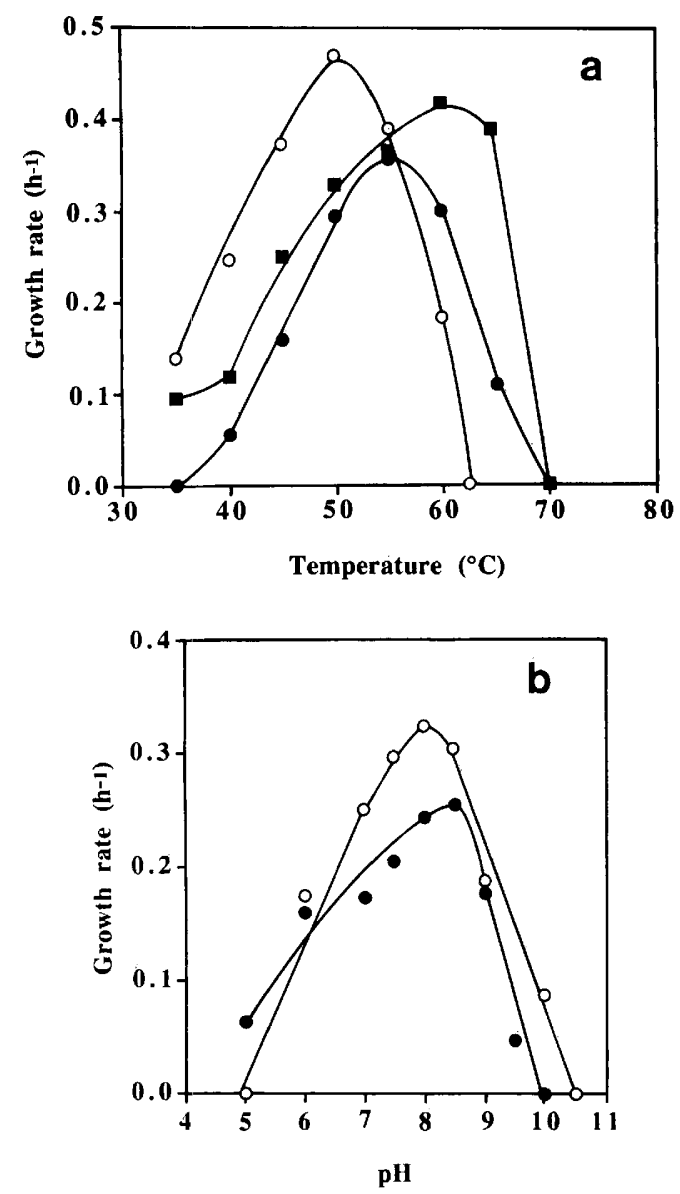

FIG. 2. Effects of temperature (a) and $\mathrm{pH}$ (b) on the growth of T. ruber DSM $1279^{\mathrm{T}}(\mathbf{\square})$, strain ALT- $8^{\mathrm{T}}(\mathrm{O})$, and strain VI-R2 $2^{\mathrm{T}}(\bullet)$.
Electron microscopy showed that strains VI-R2 ${ }^{\mathrm{T}}$ and ALT $-8^{\mathrm{T}}$ have an ultrastructure identical to that of $T$. ruber, with the distinctive outer wall layer possessing frequently spaced invaginations to the peptidoglycan (6).

The chemotaxonomic parameters which we examined indicated that the ALT and VI-R strains are related to T. ruber. Strains of the high-temperature species produce only one major glycolipid, while all T. ruber strains and the VI-R and ALT strains produce two prominent glycolipids which migrate close to each other (4). The fatty acid compositions of the species

TABLE 2. Mean fatty acid compositions of the strains examined after growth at $50^{\circ} \mathrm{C}$

\begin{tabular}{|c|c|c|c|c|}
\hline \multirow[b]{2}{*}{ Fatty acid ${ }^{a}$} & \multirow{2}{*}{$\begin{array}{c}\text { Equivalent } \\
\text { chain length }\end{array}$} & \multicolumn{3}{|c|}{$\%$ in: } \\
\hline & & $\begin{array}{c}\text { T. ruber } \\
(n=13)^{b}\end{array}$ & $\begin{array}{l}\text { VI-R strains } \\
\quad(n=5)\end{array}$ & $\begin{array}{c}\text { ALT strains } \\
(n=3)\end{array}$ \\
\hline $13: 0$ iso & 12.612 & 0.6 & 0.8 & 1.5 \\
\hline $14: 0$ iso & 13.617 & 0.7 & 0.7 & 1.7 \\
\hline $15: 1$ iso $\mathrm{F}^{c}$ & 14.413 & 2.7 & & \\
\hline $15: 0$ iso & 14.623 & 33.0 & 25.6 & 42.1 \\
\hline $15: 0$ anteiso & 14.713 & 5.5 & 26.3 & 8.1 \\
\hline $15: 0$ & 15.000 & 1.8 & 0.4 & 2.1 \\
\hline $16: 1 \omega 7 t$ alcohol & 15.408 & 0.8 & & \\
\hline $16: 0$ iso & 15.626 & 2.9 & 1.5 & 2.5 \\
\hline $16: 0$ & 15.997 & 7.6 & 6.4 & 9.1 \\
\hline Unknown 1 & 16.090 & 1.1 & 2.5 & 0.7 \\
\hline iso $17: 1 \omega 9 c$ & 16.417 & 6.5 & & \\
\hline $17: 0$ iso & 16.630 & 13.3 & 10.0 & 16.4 \\
\hline $17: 0$ anteiso & 16.723 & 3.7 & 6.4 & 2.7 \\
\hline $17: 1 \omega 6 c$ & 16.863 & 0.8 & 1.3 & 0.7 \\
\hline $17: 0$ & 16.999 & 0.8 & 0.3 & 1.2 \\
\hline $17: 0$ iso $2 \mathrm{OH}$ & 17.875 & 7.8 & 9.6 & 7.3 \\
\hline $17: 0$ anteiso $2 \mathrm{OH}$ & 17.971 & 0.4 & 3.0 & 0.6 \\
\hline $17: 0$ iso $3 \mathrm{OH}$ & 18.161 & 1.1 & & \\
\hline Unknown 2 & 19.067 & 0.6 & 1.6 & \\
\hline
\end{tabular}

${ }^{a}$ Data for several fatty acids that were present at levels of less than $1.0 \%$ in all strains are not shown.

${ }^{b} n$ is the number of strains examined.

${ }^{c}$ The double bond position of this fatty acid is not known. 
TABLE 3. Levels of $16 \mathrm{~S}$ rDNA similarity for strains ALT $-8^{\mathrm{T}}$ and VI-R2 ${ }^{\mathrm{T}}$ and related taxa

\begin{tabular}{|c|c|c|c|c|c|c|c|c|c|c|c|c|}
\hline \multirow[b]{2}{*}{ Strain } & \multicolumn{12}{|c|}{$\%$ 16S rDNA similarity to: } \\
\hline & $\begin{array}{l}\stackrel{\infty}{\infty} \\
\stackrel{\leftrightarrow}{<} \\
\gtrless\end{array}$ & 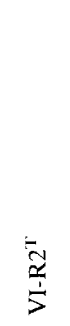 & 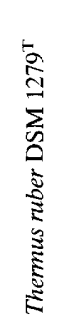 & 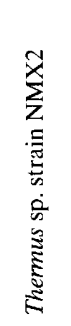 & 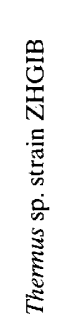 & 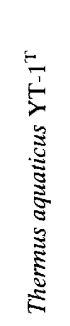 & 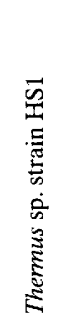 & 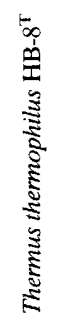 & 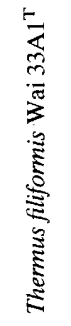 & 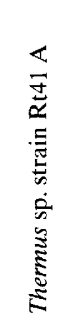 & 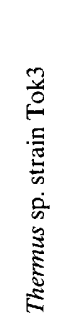 & 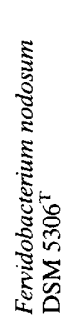 \\
\hline$\overline{V I-R 2^{T}}$ & 88.5 & & & & & & & & & & & \\
\hline Thermus ruber DSM $1279^{\mathrm{T}}$ & 91.2 & 90.0 & & & & & & & & & & \\
\hline Thermus sp. strain NMX2 & 85.8 & 85.3 & 86.0 & & & & & & & & & \\
\hline Thermus sp. strain ZHGIB & 85.9 & 86.4 & 86.3 & 96.3 & & & & & & & & \\
\hline Thermus aquaticus $\mathrm{YT}-1^{\mathrm{T}}$ & 85.8 & 86.2 & 86.6 & 96.8 & 96.8 & & & & & & & \\
\hline Thermus sp. strain HS1 & 86.5 & 85.4 & 86.5 & 95.0 & 95.3 & 96.2 & & & & & & \\
\hline Thermus thermophilus $\mathrm{HB}-8^{\mathrm{T}}$ & 86.7 & 85.7 & 86.8 & 95.3 & 95.6 & 96.5 & 99.6 & & & & & \\
\hline Thermus filiformis Wai $33 \mathrm{~A} 1^{\mathrm{T}}$ & 86.3 & 85.6 & 86.5 & 94.1 & 94.3 & 94.9 & 94.5 & 94.9 & & & & \\
\hline Thermus sp. strain Rt41 A & 86.0 & 85.3 & 86.1 & 93.7 & 93.9 & 94.5 & 94.3 & 94.7 & 99.5 & & & \\
\hline Thermus sp. strain Tok 3 & 86.2 & 85.4 & 86.6 & 94.1 & 94.1 & 94.7 & 94.7 & 95.1 & 99.5 & 99.3 & & \\
\hline $\begin{array}{l}\text { Fervidobacterium nodosum } \\
\text { DSM } 5306^{\mathrm{T}}\end{array}$ & 76.5 & 75.4 & 74.8 & 78.5 & 77.5 & 77.2 & 77.6 & 77.7 & 78.7 & 78.6 & 78.8 & \\
\hline Thermotoga maritima MSB- $8^{\mathrm{T}}$ & 78.5 & 77.8 & 76.5 & 80.8 & 80.0 & 79.9 & 80.8 & 80.8 & 80.5 & 80.1 & 80.5 & 86.3 \\
\hline
\end{tabular}

related to T. ruber are also distinctive because of the presence of a branched-chain 2-hydroxy fatty acid, 17:0 2OH iso. This fatty acid is not found in any of the high-temperature strains, although branched-chain 3-hydroxy fatty acids are present in moderate amounts in all $T$. aquaticus strains and in $T$. filiformis Wai33 A1 ${ }^{\mathrm{T}}$ (= ATCC $\left.43280^{\mathrm{T}}\right)(5)$. Moreover, the ALT and VI-R strains can be easily distinguished from each other and from $T$. ruber by their fatty acid compositions after growth at $50^{\circ} \mathrm{C}$.

T. ruber strains occur worldwide in neutral to alkaline hot springs and artificial hot water environments and form a ho-

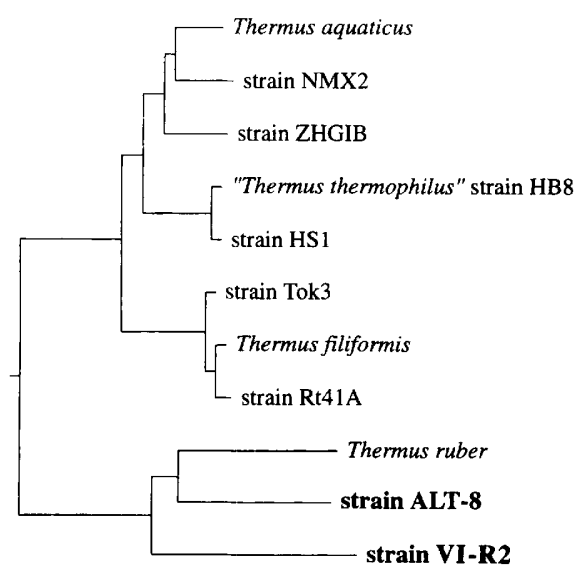

0.10

FIG. 3. Phylogenetic dendrogram showing the positions of strains ALT $-8^{\text {T }}$ and VI-R2 $2^{\mathrm{T}}$ within the radiation of the genus Thermus. Bar $=10$ inferred nucleotide substitutions per 100 nucleotides. The root organisms used were Fervidobacterium nodosum and Thermotoga maritima. mogeneous species as determined by DNA homology and fatty acid composition data $(4,6,20,23)$. The red-pigmented VI-R strains were isolated only at Vizela, and the species represented by the ALT strains, despite efforts to isolate similar organisms from another hot spring located nearby with a water temperature of $48^{\circ} \mathrm{C}$ and $\mathrm{pH} 7.9$, was encountered only at Alcafache, where the ALT strains were the only Thermus strains that could be isolated at $50^{\circ} \mathrm{C}$. Moreover, strains of $T$. ruber designated SPS were consistently recovered from the warm runoff of the hot spring (vent temperature, $68^{\circ} \mathrm{C} ; \mathrm{pH} 8.6$ ) at São Pedro do Sul, about $30 \mathrm{~km}$ from Alcafache. Therefore, we assume that physicochemical and/or biological parameters are major factors that affect colonization by these organisms and that some species could have very restricted distributions. On the other hand, the two new species of the genus Thermus represented by the VI-R and ALT strains may not have been recovered previously because most isolation procedures used for $T$. ruber-like organisms are usually performed at a temperature of 60 or $65^{\circ} \mathrm{C}(6,23,32)$.

Isolation of the yellow-pigmented ALT strains related to $T$. ruber was not expected, although yellow-orange-pigmented isolates with an optimum growth temperature of $65^{\circ} \mathrm{C}$ that were presumed to belong to T. ruber had been recovered previously from soil in the Togo Republic. The latter organisms had morphological and physiological characteristics of the genus Thermus but to our knowledge were not studied further (12).

On the basis of the results presented above, the name Thermus silvanus is proposed for the VI-R strains (type strain, strain VI-R2) and the name Thermus chliarophilus is proposed for the ALT strains (type strain, strain ALT-8).

Description of Thermus silvanus sp. nov. Thermus silvanus (sil. va' nus. L. adj. silvanus, in honor of Manuel T. Silva, a Portuguese microbiologist and immunologist). $T$. silvanus strains form rod-shaped cells; cell length is variable, and the cells are 0.5 to $0.8 \mu \mathrm{m}$ wide. Long filaments are also present. Gram negative. The cells are nonmotile, and spores are not formed. Colonies on Thermus medium are orange-red pig- 
mented and 0.5 to $1.2 \mathrm{~mm}$ in diameter after $72 \mathrm{~h}$ of growth. Growth occurs at temperatures between 40 and $65^{\circ} \mathrm{C}$ in Thermus medium; the optimum growth temperature for strain VI$\mathrm{R} 2^{\mathrm{T}}$ is about $55^{\circ} \mathrm{C}$. The optimum $\mathrm{pH}$ is between 8.0 and 8.5 ; growth does not occur at $\mathrm{pH} 5.0$ or 10.0 . Yeast extract is required for growth. The major fatty acids are 15:0 iso and 15:0 anteiso; 17:0 iso and 17:0 anteiso are present at low levels. All strains are oxidase positive and catalase negative. Nitrate is reduced to nitrite. $\alpha$-Galactosidase negative and $\beta$-galactosidase positive. Casein, elastin, gelatin, hide powder azure, and starch are degraded. Hydrolysis of fibrin is weak or negative. Strain VI-R2 ${ }^{\mathrm{T}}$ utilizes D-glucose, D-fructose, D-mannose, Dgalactose, D-xylose, maltose, lactose, D-melibiose, glycerol, Dmannitol, D-sorbitol, ribitol, pyruvate, L-glutamate, L-asparagine, L-serine, L-glutamine, and L-proline. Strain VI-R2 ${ }^{\mathrm{T}}$ does not utilize L-arabinose, L-rhamnose, sucrose, D-cellobiose, Dtrehalose, D-raffinose, meso-erythritol, galactitol, myo-inositol, acetate, succinate, citrate, salicin, or acetamide.

The DNA of strain VI-R2 ${ }^{\mathrm{T}}$ has a $\mathrm{G}+\mathrm{C}$ content of 63.6 mol\%. This bacterium was isolated from the hot spring at Vizela in northern Portugal. Strain VI-R2 ${ }^{\mathrm{T}}$ has been deposited in the Deutsche Sammlung von Mikroorganismen und Zellkulturen, Braunschweig, Germany, as strain DSM $9946^{\mathrm{T}}$.

Description of Thermus chliarophilus sp. nov. Thermus chliarophilus (chli. a. ro' phi. lus. Gr. adj. chliaros, warm; Gr. adj. philos, loving; M. L. adj. chliarophilus, warmth loving). T. chliarophilus strains form rod-shaped cells that are 0.5 to 0.8 $\mu \mathrm{m}$ wide in liquid cultures. Long filaments are also present. Gram negative. The cells are nonmotile, and spores are not produced. Colonies are yellow pigmented and 0.8 to $1.2 \mathrm{~mm}$ in diameter after $72 \mathrm{~h}$ of growth. Growth occurs at temperatures between 40 and $60^{\circ} \mathrm{C}$ in Thermus medium; the optimum growth temperature for strain $\mathrm{ALT}-8^{\mathrm{T}}$ is about $50^{\circ} \mathrm{C}$. The optimum $\mathrm{pH}$ is about 8.0; growth does not occur at $\mathrm{pH} 5.0$ or 10.0. Yeast extract is required for growth. The major fatty acids are 15:0 iso and 17:0 iso; the corresponding anteiso fatty acids are minor components during growth at $50^{\circ} \mathrm{C}$. All strains are oxidase positive and catalase negative. Casein, elastin, fibrin, gelatin, hide powder azure, and starch are degraded. Nitrate is reduced to nitrite. $\alpha$-Galactosidase and $\beta$-galactosidase positive. $\mathrm{D}$-Glucose, $\mathrm{D}$-fructose, $\mathrm{D}$-mannose, D-galactose, sucrose, maltose, D-cellobiose, D-trehalose, lactose, D-melibiose, D-mannitol, D-sorbitol, pyruvate, L-glutamate, L-asparagine, L-serine, L-glutamine, and L-proline are utilized by strain ALT-8 ${ }^{\mathrm{T}}$; D-xylose, L-arabinose, L-rhamnose, D-raffinose, glycerol, meso-erythritol, galactitol, ribitol, myo-inositol, acetate, succinate, citrate, salicin, and acetamide are not utilized.

The DNA of strain ALT $-8^{\mathrm{T}}$ has a $\mathrm{G}+\mathrm{C}$ content of 69.9 mol\%. This bacterium was isolated from the hot spring at Alcafache in central Portugal. Strain ALT $-8^{\mathrm{T}}$ has been deposited in the Deutsche Sammlung von Mikroorganismen und Zellkulturen, Braunschweig, Germany, as strain DSM $9957^{\mathrm{T}}$.

\section{ACKNOWLEDGMENTS}

This work was supported in part by European Community Biotech Programme Biotechnology of Extremophiles contract BIO2-CT930274, by the Junta Nacional de Investigação Científica e Tecnológica (grant JNICT STRA/BIO/367/92), and by the Praxis XXI Program, Portugal (grant Praxis 2/2.1/BIO/20/94).

We thank E. Stackebrandt and F. Rainey (Deutsche Sammlung von Mikroorganismen und Zellkulturen, Braunschweig, Germany) for performing the DNA base composition and 16S rDNA sequence analysis, Hans Trüper (University of Bonn, Bonn, Germany) and Walter Medeiros (University of Coimbra, Coimbra Portugal) for advice concerning the names of the organisms, and Paula M. Macedo and M. Irene
Barros (Centro de Citologia Experimental, Porto, Portugal) for the electron microscopy.

\section{REFERENCES}

1. Brock, T. D., and H. Freeze. 1969. Thermus aquaticus gen. n. and sp. n., a non-sporulating extreme thermophile. J. Bacteriol. 98:289-297.

2. Cashion, P., M. A. Holder-Franklin, J. McCully, and M. Franklin. 1977. A rapid method for the base ratio determination of bacterial DNA. Anal. Biochem. 81:461-466.

3. De Soete, G. 1983. A least squares algorithm for fitting additive trees to proximity data. Psychometrika 48:621-626.

4. Donato, M. M., E. A. Seleiro, and M. S. da Costa. 1991. Polar lipid and fatty acid composition of strains of Thermus ruber. Syst. Appl. Microbiol. 14:235-239.

5. Ferraz, A. S., L. Carreto, S. Tenreiro, M. F. Nobre, and M. S. da Costa. 1994. Polar lipids and fatty acid composition of Thermus strains from New Zealand. Antonie Leeuwenhoek 66:357-363.

6. Hensel, R., W. Demharter, O. Kandler, R. M. Kroppenstedt, and E. Stackebrandt. 1986. Chemotaxonomic and molecular-genetic studies of the genus Thermus: evidence for a phylogenetic relationship of Thermus aquaticus and Thermus ruber to the genus Deinococcus. Int. J. Syst. Bacteriol. 36:444-453.

7. Hudson, J. A., H. W. Morgan, and R. M. Daniel. 1987. Thermus filiformis sp. nov., a filamentous caldoactive bacterium. Int. J. Syst. Bacteriol. 37:431-436.

8. Jukes, T. H., and C. R. Cantor. 1969. Evolution of protein molecules, p. 21-132. In H. N. Munro (ed.), Mammalian protein metabolism. Academic Press, New York.

9. Kristjansson, J. K, S. Hiörleifsdottir, V. T. Marteinsson, and G. A. Alfredsson. 1994. Thermus scotoductus, sp. nov., a pigment-producing thermophilic bacterium from hot tap water in Iceland and including Thermus sp. X-1. Syst. Appl. Microbiol. 17:44-50.

10. Kuykendall, L. D., M. A. Roy, J. J. O'Neill, and T. E. Devine. 1988. Fatty acids, antibiotic resistance, and deoxyribonucleic acid homology groups of Bradyrhizobium japonicum. Int. J. Syst. Bacteriol. 38:358-361.

11. Loginova, L. G., L. A. Egorova, R. S. Golovacheva, and L. M. Seregina. 1984. Thermus ruber sp. nov., nom. rev. Int. J. Syst. Bacteriol. 34:498-499.

12. Loginova, L. G., G. I. Khraptsova, T. I. Bogdanova, L. A. Egorova, and L. M. Seregina. 1978. A thermophilic bacterium Thermus ruber producing a bright orange pigment. Microbiology (Engl. Transl. Mikrobiologiya) 47:456-457.

13. Manaia, C. M., and M. S. da Costa. 1991. Characterization of halotoleran Thermus isolates from shallow marine hot springs on S. Miguel, Azores. J. Gen. Microbiol. 137:2643-2648.

14. Manaia, C. M., B. Hoste, M. C. Gutierrez, M. Gills, A. Ventosa, K. Kersters, and M. S. da Costa. 1994. Halotolerant Thermus strains from marine and terrestrial hot springs belong to Thermus thermophilus (ex Oshima and Imahori, 1974) nom. rev. emend. Syst. Appl. Microbiol. 17:526-532.

15. Mesbah, M., U. Premachandran, and W. B. Whitman. 1989. Precise measurement of the $\mathrm{G}+\mathrm{C}$ content of deoxyribonucleic acid by high-performance liquid chromatography. Int. J. Syst. Bacteriol. 39:159-167.

16. Oshima, T., and K. Imahori. 1974. Description of Thermus thermophilus (Yoshida and Oshima) comb. nov., a nonsporulating thermophilic bacterium from a Japanese thermal spa. Int. J. Syst. Bacteriol. 24:102-112.

17. Prado, A., M. S. da Costa, and V. M. C. Madeira. 1988. Effect of growth temperature on the lipid composition of two strains of Thermus sp. J. Gen. Microbiol. 134:1653-1660.

18. Rainey, F. A., M. Dorsch, H. W. Morgan, and E. Stackebrandt. 1992. 16S rDNA analysis of Spirochaeta thermophila: its phylogenetic position and implications for the systematics of the order Spirochaetales. Syst. Appl. Microbiol. 15:197-202.

19. Rainey, F. A., and E. Stackebrandt. 1993. 16S rDNA analysis reveals phylogenetic diversity among the polysaccharolytic clostridia. FEMS Microbiol. Lett. 113:125-128.

20. Ruffett, M., S. Hammond, R. A. D. Williams, and R. J. Sharp. 1992. A taxonomic study of red pigmented gram negative thermophiles, p. 74. In A. M. Geirsdóttir, H. P. Brown, and T. Skjenstad (ed.), Conference and Program Abstracts on Thermophiles: Science and Technology. IceTec, Reykjavik, Iceland.

21. Santos, M. A., R. A. D. Williams, and M. S. da Costa. 1989. Numerica taxonomy of Thermus isolates from hot springs in Portugal. Syst. Appl. Microbiol. 12:310-315.

22. Saul, D. J., A. G. Rodrigo, R. A. Reeves, L. C. Williams, K. M. Borges, H. W Morgan, and P. L. Bergquist. 1993. Phylogeny of twenty Thermus isolates constructed from 16S rRNA gene sequence data. Int. J. Syst. Bacteriol 43: $754-760$.

23. Sharp, R. J., and R. A. D. Williams. 1988. Properties of Thermus ruber strain isolated from Icelandic hot springs and DNA-DNA homology of Thermus ruber and Thermus aquaticus. Appl. Environ. Microbiol. 54:2049-2053.

24. Silva, M. T., and P. M. Macedo. 1987. Improved Thiéry staining for the ultrastructural detection of polysaccharides. J. Submicrosc. Cytol. 19:677681.

25. Silva, M. T., and J. C. F. Sousa. 1973. Ultrastructure of the cell wall and cytoplasmic membrane of gram-negative bacteria with different fixation techniques. J. Bacteriol. 113:953-962.

26. Skerman, V. B. D., V. McGowan, and P. H. A. Sneath (ed.). 1980. Approved 
lists of bacterial names. Int. J. Syst. Bacteriol. 30:225-420.

27. Smibert, R. M. and N. R. Krieg. 1981. General characterization, p. 409-443. In P. Gerhardt, R. G. E. Murray, R. N. Costilow, E. W. Nester, W. A. Wood, N. R. Krieg, and G. B. Phillips (ed.), Manual of methods for general bacteriology. American Society for Microbiology, Washington, D.C.

28. Tindall, B. J. 1989. Fully saturated menaquinones in the archaebacterium Pyrobaculum islandicum. FEMS Microbiol. Lett. 60:251-254.

29. Vesey, G., P. J. Dennis, J. V. Lee, and A. A. West. 1988. Further development of simple tests to differentiate the legionellas. J. Appl. Bacteriol. 65:339-345.

30. Weisburg, W. G., S. J. Giovanonni, and C. R. Woese. 1989. The Deinococcus-
Thermus phylum and the effect of rRNA composition on phylogenctic trec construction. Syst. Appl. Microbiol. 11:128-134.

31. Williams, R. A. D. 1989. Biochemical taxonomy of the genus Thermus, p 82-97. In M. S. da Costa, J. C. Duarte, and R. A. D. Williams (ed.), Microbiology of extreme environments and its potential for biotechnology. Elsevier, London.

32. Williams, R. A. D., and M. S. da Costa. 1992. The genus Thermus and related microorganisms, p. 3745-3753. In A. Balows, H. G. Trüper, M. Dworkin, W. Harder, and K. H. Schleifer (ed.), The prokaryotes, 2nd ed. Springer-Verlag, New York. 